\title{
The Impact of Classification and Framing in Entrepreneurial Education: Field Observations in Two Lower Secondary Schools
}

\author{
Monika Diehı", Joakim Lindgren, Eva Leffler \\ Department of Education, Umea University, Sweden
}

Copyright (C) 2015 by authors, all rights reserved. Authors agree that this article remains permanently open access under the terms of the Creative Commons Attribution License 4.0 International License

\begin{abstract}
This article's purpose is to examine, on the basis of Bernstein's theory of classification and framing, how teachers express the concept and content of entrepreneurship in classroom practices in two Swedish lower secondary schools. The study is part of a national school improvement program aiming to better understand, develop and encourage entrepreneurial education and learning. The broad perspective of entrepreneurial education is used in Swedish compulsory school and thereby in this study. In 2011 the curriculum was reversed, which meant, in addition to introducing entrepreneurship, adding focus on learning outcomes. The data sample is based on observation and field notes. The results show differences between the schools and subjects. The classification is strong in both schools, but the framing differs. Differences in framing are based on characteristics of individual teachers, and to some extent subjects, rather than schools. Together with other circumstances - such as teachers' views and knowledge, school organization and subject division - the task can be perceived as challenging.
\end{abstract}

Keywords Entrepreneurial Education, Classification, Framing, Collection Code, Integrated Code, Lower Secondary School

\section{Entrepreneurial Education, an Introduction}

Entrepreneurial education has been a part of international education policy for several decades [1-4]. An entrepreneurial mindset is seen as vital for domestic growth and for sustainable local and regional development [1-4]. In Sweden, the Swedish National Agency for Education stresses "entrepreneurship" as the main idea behind the 2011 restructuring of the national school system [5]. The current Swedish curriculum explicitly places the concept at the very core of pupils' development and learning [6].

It has been argued that entrepreneurial education involves moving away from "traditional" teaching and learning; away from teacher-centered and teacher-controlled teaching and toward a focus on the students. Teachers are to be seen as mentors and supervisors in a cooperative and interdisciplinary learning process characterized by creativity, meaning-making and interactivity [7-10]. This implies profound pedagogical challenges for teachers. The question is, what are the conditions for entrepreneurial education?

There are many reasons that educational change is difficult [11]. The implementation of entrepreneurial education displays many of these difficulties. It certainly is a broad and ambitious change and consequently teachers have to work on many fronts. It has been described as poorly conceptualized $[5,12,13]$ and there has also been a lack of commitment and even resistance and resentment among teachers [14]. This paper argues that the change has also been undermined by parallel policy changes in terms of re-traditionalization. According to critics, this has resulted in a standards-based curriculum influenced by first, a technical-instrumental discourse that emphasizes form, structure and function, and second, a neoconservative discourse in which curriculum content is seen as a given and uncontested body of knowledge [15]. Thus teachers have to relate to two rather different discourses which brings to the fore the profound pedagogical issues of professional discretion. On the one hand, they have to transmit factual knowledge that is strictly regulated and evaluated for each knowledge requirement in each school subject, on the other hand, they are obliged to organize teaching that develops an entrepreneurial mindset.

Studies on entrepreneurial education often analyze policy documents in order to produce links between certain key words (curiosity, creativity, responsibility etc.) and larger social- and economic developments (often labeled "neoliberalism"). This study sets out to do something different, it seeks to explore entrepreneurial education as a 
concrete practice on the small scale by observing the pedagogical challenges of teachers in Swedish lower secondary schools who are engaged in a national school improvement program based on entrepreneurial teaching and learning.

In order to theoretically explore these challenges we draw on Basil Bernstein's [16,17] ideas on classification and framing. Bernstein's theory offers an advanced perspective on pedagogical relations and practices including issues related to power, change and knowledge that transcend dualistic divisions such as "traditional" and "entrepreneurial", which are not analytically helpful. Very briefly, Bernstein argues that a practice characterized by weak classification and framing has as an integrated code, and that one with strong classification and framing works according to a collection code. "Traditional" teaching and learning would in these terms indicate a collection code, and "entrepreneurial" teaching and learning would indicate an integrated code. However, how this plays out may depend upon the subject, the individual teachers' pedagogical views and the schools' cultures. In addition, the contradictory discourses in Swedish education policy may affect classroom practices in different ways. This study's intention is to use Bernstein's theory of classification and framing to explore the resulting differences in pedagogical practices, thus hopefully contributing to new perspectives on the conditions for entrepreneurial education.

\subsection{Aim of the Study}

The aim of this study is, on the basis of Bernstein's theory on classification and framing, to examine pedagogical classroom practices in two different schools that are involved in the same school improvement program on entrepreneurial education. The two following questions have guided the study:

- Are there any differences between the pedagogical practices in the two schools, and if so, what can we learn from them?

- Are there any differences between pedagogical practices in different school subjects, and if so, what can we learn from them?

\section{Views on Entrepreneurial Education, Challenges and Obstacles}

\subsection{Entrepreneurial Learning}

One way of clarifying the goals of entrepreneurial education is to make a distinction between narrow and broad approaches $[7,18]$. The first is associated with knowledge and skills related to starting and running a business and the general concept "entrepreneurship". The broad approach is expressed as attitudes and personal development that work toward an entrepreneurial "thinking" and acting and the concept "enterprise". In Sweden the broad approach is used in compulsory school (grades 1-9, ages 6-15) and is expressed in the Swedish curriculum [6] in the following way:

An important task for the school is to provide a general but coherent view. The school should stimulate pupils' creativity, curiosity and self-confidence as well as their desire to explore their own ideas and solve problems. Pupils should have the opportunity to take initiative and responsibility, and to develop their ability to work both independently and together with others. The school in doing this should contribute to pupils developing attitudes that promote entrepreneurship (p. 11; italics added).

The focus in the curriculum is thus on non-cognitive competencies in which the pupils are supposed to take active part in their learning processes $[6,19,20]$ By focusing on non-cognitive skills, Moberg[19] studied the fostering of entrepreneurial (non-cognitive) skills among Danish ninth-graders (aged 14-15) and found that these skills had positive associations according to school engagement among younger students. This is in accordance with a Dutch study in which the results indicated that younger pupils are more prone than older ones, to have non-cognitive traits such as self-efficacy, need for achievement, risk taking propensity and tendency to analyze [20].

However, there are concerns about what kind of education is needed to create entrepreneurial individuals. Research agrees so far, that the education has to have a point of departure in pupils' own interests and life world where the cooperation with the surrounding community plays an important role $[18,21,22]$. The pedagogical approach to entrepreneurial learning is that the pupils should be active and given opportunities to take initiative, show responsibility and work together $[23,24]$. The pupils' different skills and knowledge are important to identify in this teamwork. This kind of pedagogical approach requires a school organization in which the syllabus facilitates "longer" class periods that promote interdisciplinary work and cooperation with the surrounding community $[13,25,26]$.

Pupils' learning activity is also discussed for example Rae[25] claims that people through active learning, (i.e. the ability to learn "through" activity) develop entrepreneurial capabilities over time. Pepin[27], using Dewey's philosophy of experience, also focuses on this aspect, arguing that entrepreneurial learning through action requires special activities, activities that allow time for creative thinking, trial and error, and working with peers.

\subsection{Challenges and Obstacles}

Research also shows the challenges and obstacles schools face in this field. One obstacle is related to the concept of "entrepreneurship" and its root in the economic sector $[22,28]$. The increasing interest and understanding of social entrepreneurship, grounded in civic responsibility, has 
proven to be easier for teachers to relate to than the economic basis of entrepreneurship [21].

In Sweden, teachers are for example concerned about a lack organization, management, inspiration and support as well as timetable issues [13,29]. Other identified obstacles include the strong subject division, in which the teachers feel that they are the sole bearers of a subject [30], teachers' fear of not attaining results and thus handing over power and control to the students and teachers predetermined ideas about teaching and learning [21]. Other issues include that entrepreneurial learning is said to imply a new culture and a new rhetoric, which teachers can have difficulty relate to $[12,22]$. Yet another issue highlights the differences in the school subjects and their affordances in relation to entrepreneurial education. An interview study among Swedish teachers showed that different school subjects are ascribed different correspondence with entrepreneurial education [31]. It was found that science teachers regard their subjects as enterprising. The social subjects (together the arts and music) are regarded as enterprising per se, but mathematics is considered difficult to approach in an entrepreneurial way.

In different ways circumstances impact entrepreneurial education. Teachers need to relate to the different tensions and discourses. In the next section, this article continues with the study's theoretical framework.

\section{Bernstein's Theories}

Bernstein's[16,17] ambitions are above all, to describe the process of socialization in educational practice and to describe events within different discourses and different groups of actors. This article's purpose is to use theory to explore events in classroom practices so as to understand the enactment of entrepreneurial education. In particular, the analysis will focus on classification and framing using these concepts to map out classroom practices and determine whether they are working according to a collection code or an integrated code. To enable this Bernstein's conceptions of power and control are vital.

\subsection{Classification and Framing in Pedagogical Practices}

As argued above, the introduction of entrepreneurial education calls attention to issues of change and ways of organizing time and content in schools. Power is the ability to create, legitimize and reproduce such boundaries. Power is also used to establish changes into a given direction, it acts between different groups or categories to control and create a legitimate educational practice. Control concerns legitimate forms of communication within the different groups or categories. Power is used to set limits on who / what should be included in different groups or categories, and control concerns socialization within the group or category. Control has two functions: to reproduce and to change. This in turn depends on what the classification and framing look like.
Classification is related to power and is used by Bernstein[16] to describe the relationships between categories, for example between discourses, subjects, content, practices and actors. The classification may be stronger or weaker depending on how isolated the different categories are from each other.

Thus, in the case of strong classification, we have strong insulation between the categories and each category has a unique identity, its unique voice, its' own specialized rules of internal relations. In the case of weak classification, we have less specialized discourses, less specialized identities, less specialized voices. But classifications, strong or weak, always carry power relations. (p.21)

Framing relates to control and communication in various categories. The concept describes the types of communication available in different categories. In the long run, this also regulates what knowledge is created or is available in different categories or groups. Framing is about communication and interaction in local educational relationships, such as between parents and children or teachers and pupils. Framing is thus a way to see how relationships are regulated within a context. It's about the internal logic of pedagogical practice and it describes the nature of control over; selection of communication, sequencing, expected assimilation (learning, for example), learning criteria and the social context in which the communication (learning) occurs. Like classification, framing can be stronger or weaker. In strong framing the intermediary (e.g. the teacher) has explicit control over these factors, and in weak framing the acquirers (e.g. the pupils) seemingly have more control.

Thus, classification describes the boundaries of different discourses, and framing describes how these are realized:

Classification refers to what, and framing is concerned with how meanings are to be put together, the forms by which they are to be made public and the nature of the social relationship that go with it.(31, p. 27)

\subsection{Collection Code and Integrated Code in Pedagogical Practices}

An institution with strong classification and strong framing represents what Bernstein calls the collection code. In such an organization, everyone is specialized in different areas. Teachers in such a practice relate to each other not as teachers but in relation to their subjects. This leads to weak relationships between teachers on educational issues, and a limited scope for general discussions and educational challenges. A practice with weak classification and weak framing operates according to what Bernstein calls an integrated code. Such a practice is more vulnerable because its identity is not established and its communication with the outside world is difficult to control. On the other hand, teachers in such practices are part of strong networks and are dependent on these networks for the teaching to work. They 
are more likely to discuss and establish a shared approach based on their views of knowledge.

\section{Method}

\subsection{Data Collection and Procedure}

The main goal for the choice of data gathering in this study is to gain access to schools that have expressed interest in entrepreneurial teaching and learning by being a part of a school improvement program. For this article the starting point is data collected through observations of classroom practices. Observation provides an opportunity to examine the conditions and prerequisites for entrepreneurial education. A structured observation schedule [33] with fixed categories was created. It was based on Swedish, (and international) policy documents [1-4], and the Swedish curriculum, and course syllabi which describe the required abilities for "entrepreneurship" [6,32]. In addition, the observation protocol was so that Bernstein's theory of classification and framing could be observed. In order to absorb the situation and to observe events and behaviors not covered by the structured part of the protocol, additional field notes were made. Overall, the method can be described as a form of participant observation [33,34]. To obtain a reasonable demarcation for the study classroom observations in two lower secondary schools with different circumstances were made. The schools were situated outside major cities in Sweden. Furthermore, three different subject areas were focused on; science (chemistry, physics, engineering, biology), mathematics and social sciences (religion, history, civics and geography). Three to four weeks were spent at each school, 21 observations were made at school 1 and 31 were made at school 2 (some of which were other subjects).

\subsection{Data Analysis}

The analysis of the protocol data was made in Excel (a software package used for statistical analysis). The significance in the protocol-data was chi-squared-tested and found to be five percent (i.e., 0.05). The field notes were transcribed, categorized using a "grid" of entrepreneurial keywords, and analyzed by school and by subjects. This, increased the data's accuracy of data provided a more complete picture of the phenomenon $[33,35]$.

\subsection{Description of the Participating Schools}

\section{School 1}

This school is situated in a fairly wealthy middle-class white area where housing mainly consists of villas. This lower secondary had about 150 pupils (grades 7-9, ages 13-16). The pupils worked a lot with computers, each pupil had his or her own. Most assignments, instructions and submissions requirements necessitated access to computers.
This school has tried different interdisciplinary working methods for teachers and pupils. This resulted in schedule merging that made it possible to have longer class periods than is typical in Swedish schools (90-120 minutes instead of 40-60). At the time of data gathering pupils were working primarily within subjects or subject blocks. The school has participated in several contests and has an outspoken ambition to work according to the concept of entrepreneurial education. The teachers felt that the principal supported and encouraged them to work entrepreneurially.

\section{School 2}

This lower secondary school is situated in a suburban community with mixed housing. It had around 320 pupils (grades 6-9, ages 12-16) about one third of whom had ethnic background other than Swedish. Regarding equipment such as computers, there was a special classroom where stationary computers were available if teachers had booked the room in advance. The teachers' and pupils' work was organized with subject and subject blocks as a base. The lessons normally lasted for 40 to 60 minutes. The school featured activities and thematic work regularly during the year, some lasting for a day, and others for a whole week. These often required some changes in the teachers' schedules. In this school teachers and even the principal, often said that they hadn't made much progress on entrepreneurial education. The teachers did feel encouraged and supported by their principal, however.

\section{Results and Analysis}

First the schools will be described and analyzed. This will be done through a general description, including typical examples, of the classroom practices at each school. General description may risk to violate the variations within each school, but this method provides an overall picture of each observed school. The analysis will be done in accordance with Bernstein's [16,17] concepts of classification and framing. Next the different subjects, regardless of school, will be analyzed in the same way.

\subsection{Pedagogical Practices in Two Different Schools}

\section{School 1}

In a typical classroom practice, teachers introduced themes that the pupils were to work with for a couple of weeks, others had a more specific aim for each lesson. For example the pupils in one class built their own towns, either in a computer program or by using other materials. Many vital aspects such as local communication, water supplies, environmental issues, and so on were considered. Other examples include an assignment in which a class made a movie about law and order, and in which each student, built and program a Lego car for it to manage to run a certain track. All lessons started with an introduction by the teacher, after 
that, the pupils started working, often in groups or pairs. Some lessons were part of a bigger theme and worksheets were used to track the progress of the lager project throughout each lesson. The teacher explained steps which could be followed in the pupils own pace. Extra assignments were provided if there was time left. During these lessons the pupils worked rather intensely. Other lessons were less structured, and the pupils had to organize their tasks themselves, the conditions, such as due dates, group membership, time for, and form of submission, were changed now and then. The field notes show that, during these lessons, the pupils sometimes seemed uncertain about what to do and had difficulties getting started, instead talking about other topics and playing with their cell phones.:

Many (pupils) do nothing but play with their cell phones. After a while an increasing number of the pupils start working, but there seem to be pupils that don't know what to do or don't understand the task.

In these situations the teachers commented on the pupils' behavior and urged them to get on with their tasks. The overall relationship between teachers and pupils was good and teachers often showed interest in the pupils' personal lives.

Some lessons lasted for 90-120 minutes, and others were 40-50 minutes long. The shorter lessons were more specifically led by the teachers. The overall organization was that each teacher planned and taught his or her own subjects. The observations showed plenty of room for the pupils to use and develop entrepreneurial abilities such as creativity and responsibility, to explore ideas and to work with others. The practices described above the teachers' rhetoric, when answering pupils' questions, enhanced the students' skill development at times.

\section{Classification}

This school culture can be described as working in accordance with a rather strong classification as the isolation between different subjects was rather strong $[16,17]$. On the other hand, teachers sometimes mentioned or integrated other subject areas into the tasks, and attempts were made to cooperate with the surrounding community. Even though teachers occasionally planned some work areas together with colleagues, these were within the same subjects and the specific planning and realization was up to the individual teacher.

\section{Framing}

At this school pedagogical practices using both strong and rather weak framing $[16,17]$ were observed. Lessons or parts of a theme sometimes began with weak framing but were often characterized by changing instructions, options and requirements. Using Bernstein's vocabulary the sequencing, when to do what, as well as time and pace of assignments were not entirely clarified or fixed. This, at occasion, resulted in uncertainty among the pupils and implied the same for the teacher. Pupils' confusion and uncertainty may have led to difficulties getting started and temptations to avoid the assigned tasks by talking about non-school related issues or playing with cell phones. A teacher's uncertainty might be based on his or her ambition to establish a "creative atmosphere" not seeing immediate results, could lead to new preconditions for the pupils. Framing is about who controls what and how meaning is put together [16,17]. These changed preconditions can be seen as strengthening the framing, to regain some control and to ensure that the criteria (learning outcomes) are fulfilled. Lessons or themes with rather strong framing were characterized by step by step instructions that kept the pupils rather busy throughout each lesson. Thus, the sequencing and the expected assimilation was regulated but the time, pace, communication and order in the classroom were rather unregulated. In both these settings there was room for pupils to develop and practice entrepreneurial skills. In this school lessons with strong framing were also observed. These were teacher led, and pupils were required to do a certain amount of work each lesson, to work quietly and to ask for help if needed. Observation indicates that few entrepreneurial skills were practiced or developed during these lessons.

\section{School 2}

At this school the classroom practices followed more or less the same structure. Lessons most commonly started with an introduction and instructions from the teacher who then asked the pupils to work on with the tasks. The tasks could be continuing work from the books, following an instruction sheet during, for example a lab, or answering fixed questions. In these settings the teacher walked around in the classroom and helped pupils who had gotten stuck or who had questions. Sometimes the lessons were more like lectures and called for the pupils' attention throughout the class. On one occasion a project that lasted for a longer period of time (2-3 weeks) was observed. The pupils worked in teams and built a dragon, by following an instruction sheet. Older pupils (grade 9, age 15-16) mostly were very focused on their assignments, but the teachers often commented on behavioral issues among the $7^{\text {th }}$ - and $8^{\text {th }}$-graders. For example some pupils, especially boys, were asked to keep quiet or urged to change places in order to bring more order to the classroom. Here is an example from the field notes:

Teacher (T): That's enough now, boys; there is not much written about this in the book, so you have to listen now ... John, please!

[The teacher asks him a question, but he cannot answer.]

Pupil (P): I don't know.

(T): Maybe one of you should move over here [looking at the boys, pointing at a place in the front of the classroom].

\section{[Nothing happens.]}

(T): Some of you are talking... well, we are waiting [to be able to continue the lesson].

The teachers did not hesitate to tell the pupils how they 
were doing on the schoolwork, even if it was bad, but they also commented on the pupils' behavior. In spite of this, the teachers seemed keen on having good relations with the pupils and often showed interest in their personal lives. Most of the lessons lasted for 40-50 minutes and were led by the teachers. The observations sometimes showed, though not to a very high degree, teachers being concerned about students developing skills like initiative, curiosity, creativity, risk-taking, reflection, analysis and argument. Group work sometimes occurred but communication skills were not practiced thoroughly; for example, students were not asked to present a topic to the class. Essentials trait for pupils were to take responsibility to show others respect and to cooperate when required.

\section{Classification}

This school culture can be described as having a strong classification on a daily basis. The isolation between the subjects was strong. Teachers planned and realized their own lessons although they sometimes shared ideas and teaching material with others within the subjects. Bernstein[17] describes strong classification as each category having a unique identity, voice and rules for internal relations, which could be observed in this pedagogical practice. During observations the school arranged a theme that all pupils to took part of. It was planned by a few teachers and other teachers helped carrying it out, which to some degree meant changes in the pupils' and teachers' schedules. This can be seen as a temporary weak classification but it did not affect the school's everyday practice.

\section{Framing}

In this pedagogical practice the framing in general was rather strong only a few exceptions were observed. Most of the time the teachers regulated criteria, sequencing, time, pace and order in the classroom. There was room for communication when the pupils were working in peers and groups or when they were helping each other with different assignments. However the communication was mostly controlled by the teacher, either by asking the pupils to be quiet while working or by asking students to answer questions. Framing, according to Bernstein[16,17], describes communication in different categories and thereby regulates what knowledge is created. Bernstein[17] points out that in a situation with strong framing the pace for the expected credit performance (of learning) is high and time is perceived as insufficient. This in turn has two implications. First pupils learn that only certain type of questions can be asked and the teacher learns that only certain kind of answers can be given. Secondly, strong framing likely leads to reproduction of existing knowledge rather than encouraging pupils to explore what lies beyond the already taken for granted. Teachers at this school expected the pupils to do what they were told, and answer the questions that were asked, and most of the time the students complied, in the higher grades, pupils were even eager to do so.

\subsection{Framing in Both Schools}

The figure below shows the strength of framing at the two schools.

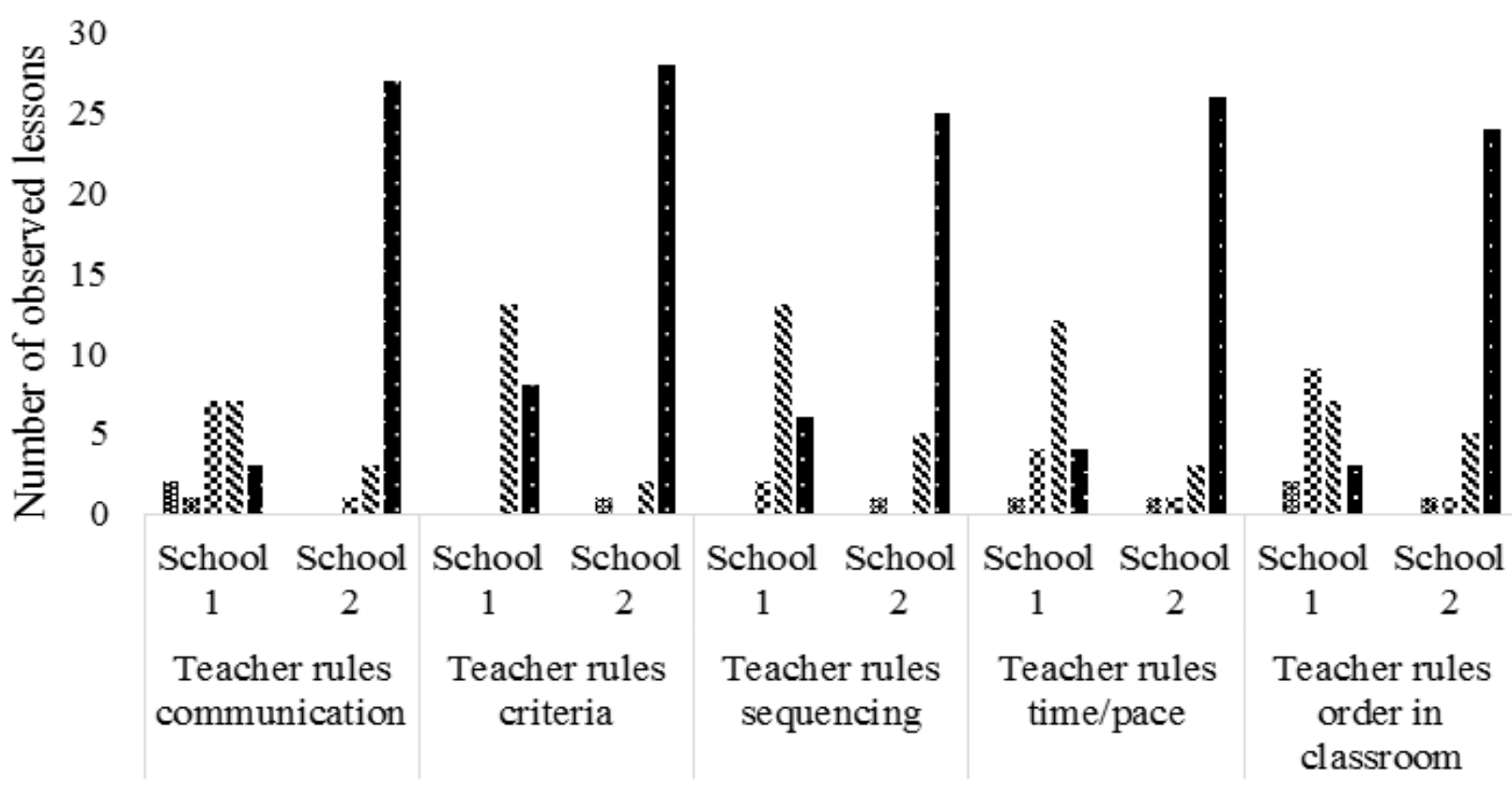

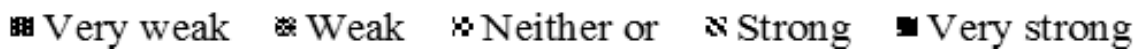

Figure 1. The figure shows the strength of framing regarding who rules communication, criteria, time/pace and order in the two different schools. ( $\mathrm{p}<0.05$ ) 
The results show that the framing is stronger at all levels at school 2, than at school 1. The main difference can be seen when it comes to communication and order in the classroom. At school 1 the teachers to a greater extent let the pupils interact and be part of the communication. This weaker framing could perhaps be seen as a question about the actual purpose of the communication. There was somewhat more room for negotiation about sequencing, time /pace and criteria at school 1 than at school 2.

To sum up, both schools worked according to a collection code but the overall result showed stronger framing at school 2 , which implies that the collection code was more obvious at school 2. Bernstein[16,17] argues that knowledge, in a practice that operates according to the collection code, is most likely seen as something that can be transmitted to students who are expected to be able to transform the acquired knowledge to phenomena later in life. Knowledge is given and measurable, and if students fail the fault is with them, not in the practice. Socialization in this educational code implies that alternative ways of looking at reality are eliminated. Bernstein[16,17] describes the collection code (strong classification and framing) as teachers having a high degree of control with weak relationships between teachers regarding educational issues and challenges. This description fits well with the observed practice at school 2. Classification and framing provide rules for the educational code. When classification and framing become weaker, changes occur; in discursive and transmission practice, in psychological defense mechanisms, in the teacher-student role, in knowledge and in the whole educational consciousness $[16,17]$. The teachers observed at school 1 sometimes worked together and tried different ways to encourage the development of entrepreneurial skills among the pupils. Following Bernstein[17] this indicates that they looked upon their specialized knowledge in a different way than did the teachers in school 2, allowing for a new basis for consensus in regard to interests and resistance. In other words the teachers at school 1 , move toward an integrated code.

In addition to the above rough categorization of the schools, some differences appeared within and between the different observed subject and subject blocks.

\subsection{Differences Within and Between the Subjects}

The subjects observed in this study were social science, science and mathematics. In addition, different classroom practices within and between the subjects were observed.

\section{Social Science}

In social science, many lessons were part of an ongoing project. This implied that the pupils got instructions at the beginning of, for example, a three-week period, and were encouraged to ask for help along the way. Previously mentioned examples include the project in which students built a city. Field notes from this lesson reveal that:

"The lesson is characterized by discussion, cooperation and creativity; the task seems to engage the pupils, and they seem to enjoy the work"
Other examples include creating a movie about law and order, comparing different countries' governments, and identifying a key social issue to advocate for. For the latter project, each student's goal was to figure out on what level (political or administrative) the issue needed to be presented and with whom it needed to be discussed. Pupils then determined how to contact key figures and reach out with the desired message. The tasks were broadly presented, and the frames were rather open; occasionally, the preconditions were changed. The different tasks were required to be reported in different ways: through a written submission, a test, a completed product (e.g., a movie) or an oral presentation. Here is an example of a comment from a teacher after an oral presentation:

\section{(T): Stina, you haven't elaborated your reasoning enough.}

When the plans for the city were presented, a representative from the local community was invited to listen and comment. The "project-natured" lessons mostly lasted for 90-120 minutes. Other observed lessons lasted 30-50 minutes and were more like lectures, in which the pupils were to listen, make notes and answer the teachers' questions. On several occasions, the pupils worked with old national tests, trying to answer the questions themselves before receiving the correct answers from the teacher.

\section{Classification and Framing}

On one occasion, a visitor from the "world outside" came to watch a presentation. Bernstein[17] claims that a move from a collection code to an integrated code means closed schools becoming more open, allowing the outside world into the school in new ways. This was a rare incident, though the teacher claimed ambitions to make them more frequent. In general the classification in the social sciences was rather strong, as there was no collaboration with other subjects. The framing, on the other hand, alternated between strong and weak, depending on the teacher. Weak framing meant new conditions for the pupils to relate to, which in turn seemed to imply time-consuming uncertainty and confusion. However, the pupils were forced to solve problems themselves. One example was a lively discussion about the content of a movie. As the teacher was helping others outside the classroom, the involved pupils had to find a solution on their own. On another occasion, parents got involved and contacted the teacher (outside world into school). Bernstein[17] argues that strong framing means an educational practice that operates in the past; weak framing, on the contrary, operates more in the present. If the framing is weak, one would expect the transfer of knowledge to be, to a greater extent, oral, and for the learning to be characterized more by cooperation than by individual activity.

\section{Science}

Many of the science lessons were in preparation for the upcoming national tests. These were mostly organized as whole-group lessons, with the teacher asking, pupils 
answering and the teacher confirming or explaining. Some lessons had a lecture-like character, others were laboratorial and still others were part of an ongoing multi-week project. During lessons on technology, the pupils were given rather precise instructions to build and construct for example mini cars and windmills, sometimes individually but often in pairs or groups, and try out different solutions (trial and error) to get them to work. These lessons were permeated by a great deal of creativity, cooperation and constructive communication among pupils as well as adequate and proactive feedback from the teacher. Here is an extract from the field notes:

The pupils seem to respect their teacher, and the teacher seems to take serious interest in the pupils' work, both regarding feedback and to check out how things are going during the lesson (if they understand, if they are making progress and so on). The teacher discusses solutions and asks the pupils developing questions.

The tasks were constructed in a way that compelled understanding and reflection, which was not the case during other observed lessons, in which "doing" seemed to be the focus. Again, the nature of the lesson seemed to depend on the teacher's ambitions and realization skills.

\section{Classification and Framing}

The classification was strong, in the same way as in the social science subjects. Regarding framing, the science practices were quite different from those in social science. A common setup was the teacher leading the communication, criteria, sequencing, pace and classroom order. This indicates strong framing. The previously described technology lessons were conducted using a rather detailed instruction sheet (containing sequencing and criteria), but after a short introduction, there was plenty of time for the pupils to elaborate on the task, to discuss it with peers and the teacher, to try out solutions and so on. The class periods were often up to 120 minutes, the working atmosphere was calm and the teacher almost never had to reprimand the pupils. The teacher seldom provided the pupils with "correct" answers but often discussed, encouraged and asked questions about their findings. Bernstein[17] claims that in a pedagogical practice with strong framing, the pupils receive praise for jobs well done from an individual point of view while in a weaker framing they would be encouraged and had their results compared to those of their classmates. In that sense, among others, this practice can be described as having rather weak framing.

\section{Mathematics}

Virtually all lessons in mathematics followed the same pattern, regardless of teacher and school. The lessons lasted for 40-50 minutes, and the most common structure was the teacher beginning with an explanation of how to solve a mathematical problem, followed by the pupils working in their math books and raising their hands if they encountered problems. The working atmosphere was mostly characterized by silence or pupils helping each other in pairs, as was often required by the teachers. The pupils had to take responsibility for their own work, which often involved completing a certain number of pages in their books; if they were not done in time, they had to finish the assignments at home. This can be seen in the field notes:

The pupils were given a sheet of paper with a plan for the coming five weeks. The topic is fractions. It is specified which pages are to be done each day.

At the end of the lesson the teacher writes on the blackboard: Homework for the week. :

- Keep up with the planning, work at home if needed

On one occasion, a teacher discusses with $7^{\text {th }}$ graders an assignment in which they will make a movie about different figures. In the higher grades, more time was spent on practicing for the upcoming national tests.

\section{Classification and Framing}

In the mathematics lesson, both classification and framing were very strong, and few attempts to weaken any of them were observed. The teachers mostly had explicit control over the communication, sequencing, expected assimilation, criteria and social context. This indicates strong framing and has an impact on what knowledge is available and created [16]. In general, teachers seemed to struggle to find a balance between getting as many pupils as possible to understand on the one hand, and keeping up with the lesson plan on the other. Bernstein[16] claims that time is seen as insufficient in a teaching situation with strong framing, which can be observed in different ways (e.g., the type of homework shown above, intense preparation for national tests, and putting off the movie project until the next semester). 


\subsection{Framing within the Subjects}

In the figure below framing within the subjects is visualized.

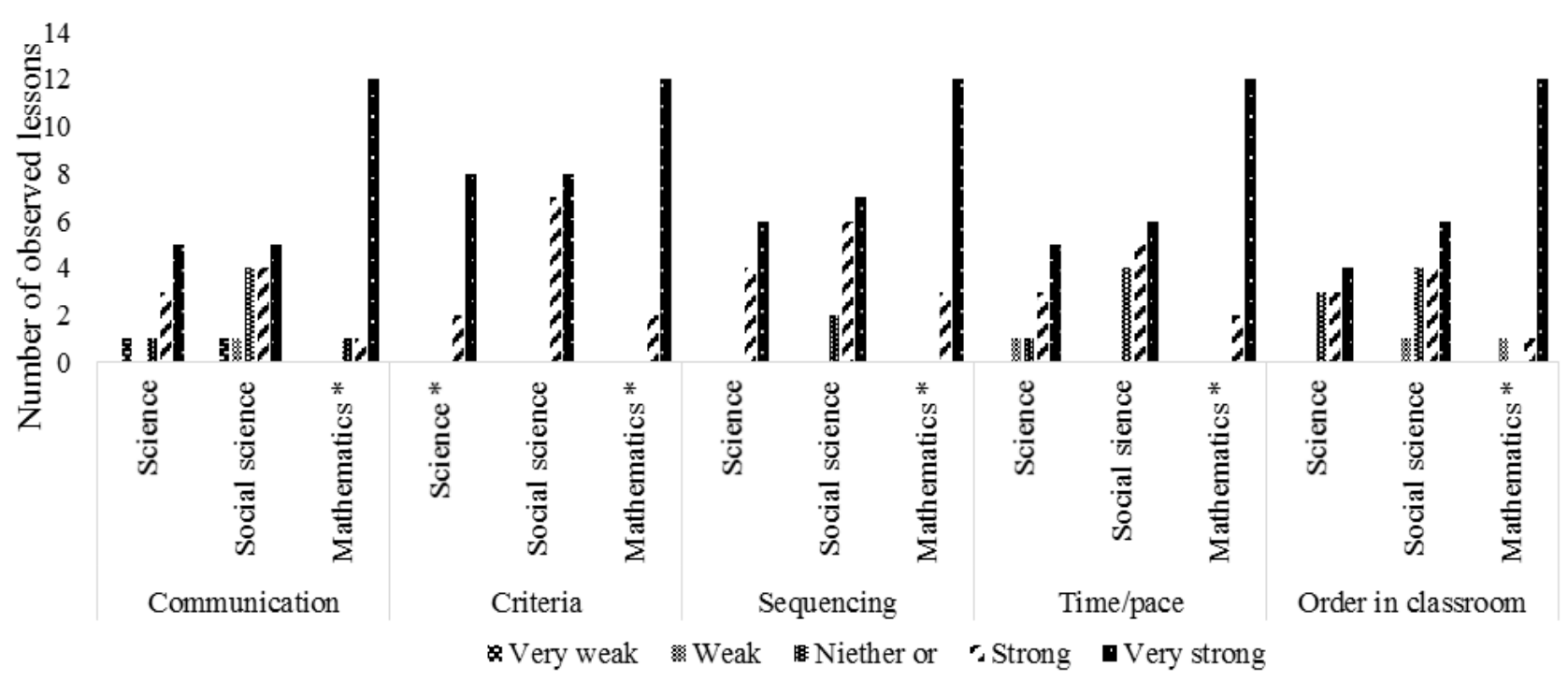

Figure 2. The figure shows to what degree teachers in in the observed practices ruled the communication, criteria, sequencing, time/pace and order in the classroom. ${ }^{*}=(\mathrm{p}<0.05)$

The general result shows that framing, regardless of subject, is strong and that pedagogic relationships are primarily ruled by the teachers. However, there are some differences between the subjects. In social sciences, there is more room for the pupils to interact and influence the pedagogy regarding communication and, to some degree, pace. The same is true for science, though not to the same extent. Mathematics is the subject in which the framing is strongest, as the teachers have the most control over all the pedagogic relations.

There are different practices not just between but also within subject areas. The overall result indicates a strong classification and isolated subjects. The framing seems to depend on the subject and the teacher's approach. The pedagogical practices are characterized by a collection code, but the dominance of this code fluctuates. In some cases (e.g., social science in school 1) the collection code, at least initially, is so invisible that it could be said to move toward an integrated code; even though the classification is strong, the framing is weaker.

\subsection{Conclusions}

Table 1 below shows an overall picture of the differences between the schools, as well as the differences between, but also within the subjects. The table visualizes the outcome of entrepreneurial education and how it can be understood according to Bernstein's theories of classification and framing. Differences between the schools is more easy to clarify than differences between the subjects as they represent both schools and to a great extent are due to individual teachers. 
Table 1. The table shows a schematic view of the results according to entrepreneurial education and Bernstein's theories

\begin{tabular}{|c|c|c|c|c|c|}
\hline $\begin{array}{c}\text { Entrepreneurial } \\
\text { Education }\end{array}$ & School 1 & School 2 & Social Science & Science & Mathematics \\
\hline $\begin{array}{l}\text { Broad/non-cognitive } \\
\text { approach (focus in } \\
\text { Swedish compulsory } \\
\text { education) }\end{array}$ & $\begin{array}{l}\text { Efforts and ambitions } \\
\text { to realize the } \\
\text { implications of a } \\
\text { broad approach } \\
\text { observed to a rather } \\
\text { large extent. } \\
\end{array}$ & $\begin{array}{l}\text { Efforts and ambitions } \\
\text { to realize the } \\
\text { implications of a } \\
\text { broad approach } \\
\text { observed to a rather } \\
\text { small extent. } \\
\end{array}$ & $\begin{array}{c}\text { Differences } \\
\text { depending on } \\
\text { individual teachers. }\end{array}$ & $\begin{array}{c}\text { Differences } \\
\text { depending on } \\
\text { individual teachers. }\end{array}$ & $\begin{array}{l}\text { More or less no } \\
\text { efforts observed. }\end{array}$ \\
\hline $\begin{array}{c}\text { Developing } \\
\text { entrepreneurial skills }\end{array}$ & $\begin{array}{l}\text { Rather many skills } \\
\text { were practiced. }\end{array}$ & $\begin{array}{l}\text { Rather few skills } \\
\text { were practiced. }\end{array}$ & $\begin{array}{c}\text { Differences } \\
\text { depending on } \\
\text { individual teachers, } \\
\text { in general rather } \\
\text { many skills were } \\
\text { practiced. }\end{array}$ & $\begin{array}{c}\text { Differences } \\
\text { depending on } \\
\text { individual teachers, } \\
\text { in general rather } \\
\text { many skills were } \\
\text { practiced. }\end{array}$ & $\begin{array}{l}\text { Pupils' responsibility } \\
\text { for their own work } \\
\text { was the skill most } \\
\text { practiced. }\end{array}$ \\
\hline Surrounding society & $\begin{array}{l}\text { Some cooperation } \\
\text { with the surrounding } \\
\text { society during the } \\
\text { time for } \\
\text { observations. }\end{array}$ & $\begin{array}{l}\text { No cooperation with } \\
\text { the surrounding } \\
\text { society during the } \\
\text { time for } \\
\text { observations. }\end{array}$ & $\begin{array}{l}\text { Some occasions } \\
\text { observed. }\end{array}$ & $\begin{array}{l}\text { No occasions } \\
\text { observed. }\end{array}$ & $\begin{array}{l}\text { No occasions } \\
\text { observed. }\end{array}$ \\
\hline Team work & Rather frequent. & Not so frequent. & $\begin{array}{c}\text { Differences } \\
\text { depending on } \\
\text { individual teachers, } \\
\text { rather frequent. }\end{array}$ & $\begin{array}{c}\text { Differences } \\
\text { depending on } \\
\text { individual teachers, } \\
\text { rather frequent. }\end{array}$ & Not observed. \\
\hline Syllabus, class periods & $\begin{array}{c}\text { Often } 90-120 \\
\text { minutes }\end{array}$ & $\begin{array}{c}\text { Mostly 40-60 } \\
\text { minutes. }\end{array}$ & $\begin{array}{c}\text { Different depending } \\
\text { on school }\end{array}$ & $\begin{array}{c}\text { Different depending } \\
\text { on school }\end{array}$ & 40-60 minutes. \\
\hline $\begin{array}{c}\text { Syllabus, } \\
\text { interdisciplinary work }\end{array}$ & $\begin{array}{c}\text { Few occasions } \\
\text { observed (on a } \\
\text { regular basis) }\end{array}$ & $\begin{array}{c}\text { No occasions } \\
\text { observed (other than } \\
\text { when working in } \\
\text { shorter themes) }\end{array}$ & $\begin{array}{l}\text { Few occasions } \\
\text { observed. }\end{array}$ & $\begin{array}{c}\text { Few occasions } \\
\text { observed. }\end{array}$ & None observed. \\
\hline Learning by doing & Rather frequent. & Not so frequent. & $\begin{array}{c}\text { Differences } \\
\text { depending on } \\
\text { individual teachers, } \\
\text { rather frequent. }\end{array}$ & $\begin{array}{c}\text { Differences } \\
\text { depending on } \\
\text { individual teachers, } \\
\text { rather frequent. }\end{array}$ & Not observed. \\
\hline \multicolumn{6}{|l|}{ Bernstein's Theories } \\
\hline Classification & Rather strong & Strong & Strong & Strong & Strong \\
\hline Framing & $\begin{array}{c}\text { Both strong and } \\
\text { rather weak, } \\
\text { depending on } \\
\text { individual teachers. }\end{array}$ & Rather strong & $\begin{array}{c}\text { Both strong and } \\
\text { rather weak, } \\
\text { depending on } \\
\text { individual teachers. }\end{array}$ & Rather strong & Strong \\
\hline Code & $\begin{array}{l}\text { Collection code } \\
\text { moving towards an } \\
\text { integrated code. }\end{array}$ & Collection code & & & \\
\hline
\end{tabular}

\section{Discussion}

The aim of this study was, based on the Bernstein's theory of classification and framing, to examine pedagogical classroom practices in two schools involved in a school improvement program for entrepreneurial education. The first research question focused on the differences between the pedagogical practices of the two schools. The results indicate that school 1 to a greater extent than school 2 had ambitions, and was working toward an integrated code. At school 1 this could be observed through longer class periods and lessons that often had a project based nature, pupils also worked more often in teams and were invited to take more initiatives and responsibility at school 1 than at school 2 $[23,24,27]$. On occasions the surrounding community was involved in school activities and tasks that connected to the pupils interests and life worlds were given [18,21,22]. At school 1 teachers occasionally made efforts give control
$[21,16,17]$ to the pupils. However, when doing this a fear of not attaining results often seemed to take over, and this resulted in gradual changes in the tasks' framing $[16,17]$. We suggest that this can be understood in terms of 're-framing'. At school 2 the overall practice was more of a collection code, teachers exerted power and control to a greater extent and were more concerned about measurable results $[21,16,17]$.

The second research question highlights the impact of framing and classification in relation to different school subjects. The results showed that social science and science lessons involved both project-based and traditional teacher-led lessons. However, the social science and science lessons both included working methods like discussions and teamwork which were sometimes related to pupils' interests [cf 30,31]. During project-based lessons, the pupils had opportunities to find solutions for how to present their knowledge and to reflect on their learning. In social science 
lessons the surrounding community was involved in tasks related to actual social issues [31]. The teacher role thus included different approaches. One was to lead the pupils' learning within the subject and one was to teach the subject. The pupils' role was also twofold, to listen, discuss and find solutions or to listen, remember and repeat the right answers. In mathematics the teachers' role was to give the right answer and to make sure that the pupils followed the schedule. The pupils were responsible for following the schedule, working individually and making sure that they knew the right answers. This study's findings indicate difficulties in attaining an overall entrepreneurial attitude. Individual teachers can be engaged and do their best in their own practice, but they are not able to influence matters such as organization, management, schedules and lack of inspiration or support. [13,31]. Individual initiatives do not seem to have a general impact in the observed collection code practices. In addition, as Leffler[31] shows, teachers may believe that some subjects are easier and more suitable for teaching entrepreneurially (e.g. social science and some science subjects) than others (e.g. mathematic). This study confirms that practice works in accordance with those results. Furthermore the study implies that teachers who tried to work in accordance with the broad view of entrepreneurial education used different methods to address the task. Weak framing seemed to bring about uncertainty, but moderate framing had the opposite impact on both teachers and pupils.

Flink and Stoll[37] express a need for restructuring - a change in fundamental structures to enable school development, which is not a feasible task for individual teachers at a school. Reculturing[37] is about developing new values, beliefs and norms to connect the purpose of education to organization, structures, cultures, leadership as teachers' work and environments. For this to happen a joint sense of how to handle everyday situations, in which every detail fits together and make sense, is essential [35]. Otherwise the practice risks becoming fragmentized, uncertain and insecure for both pupils and teachers [35], which to some extent was observed in this study.

Even if school improvement succeeds and the previously mentioned aims would be reached, the re-traditional policy changes are seen as obstacles for implementing and obtaining a practice in accordance with entrepreneurial education. In 1975 Bernstein[16] pointed out that the British, educational system was undergoing "a change from curriculum of the collection type to curriculum of the integrated type" (p.84). He claimed that the social consequences of this shift would bring about disturbances in the educational institutions. The traditional authority relationships would be altered, including those regarding status and range of content, relationships between teachers and between pupils, and openness, which allows the outside world to penetrate schools in new ways. Turning to the integrated code "the moral basis of our educational choices will become explicit and we must expect considerable conflict of values" (p.84).

2015, there are still policy movements towards an integrated code, advocates for the broad view of entrepreneurial education might be the most visible. However the policy changes are, to say the least, contradictory. The Swedish curriculum has undergone a major reform significantly reshaping pre-school, compulsory and upper secondary schools in 2011. The reform is said to be a part of an international policy discourse and to represent a denationalized and instrumental conception of education [38]. This has resulted in a standards-based curriculum influenced by a technical-instrumental discourse that emphasizes form, structure and function in addition to a neoconservative discourse in which curriculum content is seen as a given, uncontested body of knowledge [15]. As Olovsson[40] has shown, assessments increasingly focus on' performance in relation to the steering documents and more regulations practices restrict teachers' and students' autonomy. In addition, the rise of Swedish national control, such as the reintroduction of national school inspections in 2003 [38], has led to conditions that cannot be overlooked when examining teachers' work and classroom practice. The tendency toward control, measurement and comparison may imply a focus on teachers' abilities to securely bring about certain outcomes and not whether the 'outcomes themselves are desirable' [39, p.35].

Entrepreneurial education focuses on non-cognitive skills and knowledge that is difficult to measure, and it is most likely to be developed in a practice with an integrated code. Measurable, controllable, given and uncontested knowledge in a standards-based curriculum, suggests a pedagogic practice with a collection code. In between these extremes are the teachers. They are the ones who are to handle these contradictions in their daily pedagogical practice. Further research is needed in order to understand how teachers perceive and take on this challenge.

\section{Acknowledgements}

This paper is part of a $\mathrm{PhD}$ project financed by the Swedish independent research institution IFOUS (Innovation, Research and Development in School) and the Umeå School of Education, Umeå University, Sweden.

\section{REFERENCES}

[1] OECD. Towards an "Enterprising" Culture: Challenge for Education and Training, OECD, France, 1989.

[2] OECD. Fostering Entrepreneurship. The OECD Job Strategy, OECS, France, 1998.

[3] European Commission. Europe 2020. A European strategy for smart, sustainable and inclusive growth, European Commission, Belgium, 2010.

[4] European Commission. Entrepreneurship education at school 
in Europe - National strategies, curricula and learning outcomes, Eurydice, Belgium, 2102

[5] Nordin, A. Centralisering I en tid av decentralisering Om den motsägelsefulla styrningen av skolan. Örebro universitet, Sweden, 2014.

[6] Swedish National Agency for Education. Läroplan för grundskolan, förskoleklassen och fritidshemmet 2011, Skolverket, Sweden, 2011.

[7] Erkkilä, K. Entrepreneurial Education, Garland Publishing, England and USA, 2000

[8] Gibb, A. A. Entrepreneurial Culture and Education Understanding Enterprise Education and Its Links with Small Business, Entrepreneurship and Wider Educational Goals, Sage, International Small Business Journal, Vol. 11, No. 3, 11-34, 1993

[9] Kyrö, P. Entrepreneurial learning in a cross-cultural context challenges previous learning paradigms. In P. Kyrö \& C. Carrier (eds). The Dynamics of Learning Entrepreneurship in a Cross-Cultural University Context. University of Tampere, Finland, 2005.

[10] Lackéus, M. Entrepreneurship in education - What, why, when, how, Entrepreneurship360 Background paper, OECD, France, 2015.

[11] Hargreaves, A. Extending Educational Change, International Handbook of Educational Change. Springer, USA, 2005.

[12] Shacklock, G., Hattam, R. \& Smyth, J. Enterprise Education and Teachers Work: Exploring the Links, Taylor \& Francis, Journal of Education and Work, Vol. 13, No. 1, 41-60, 2000.

[13] Sagar, H. Teacher Change in Relation to professional Development in Entrepreneurial Learning. University of Gothenburg, Sweden, 2013.

[14] Lackeus, M. \& Moberg, K. Entreprenörskapsutbildning Från ACB till PhD, Etrepreneörskapsforum, Sweden, 2013.

[15] Sundberg, D. \& Wahlström, N. Standard-Based Curricula in a Denationalised Conception of Education: The Case of Sweden, Sage, European, Educational Research Journal, Vol. 11, No. 3, 342-356, 2012.

[16] Bernstein, B. Class, Codes and Control, Volyme 3, Towards a Theory of Educational Transmission, Routlege \& Kegan Paul, Great Britain, 1975.

[17] Bernstein, B. Pedagogy Symbolic Control and Identity Theory, Research, Critique, Taylor \& Francis, 1996.

[18] Jones, B \& Iredale, N. Enterprose education as pedagogy, Emerald, Education + Training, Vol. 52, No. 1, 7-19, 2010.

[19] Moberg, K. Assessing the Impact of Entrepreneurial Education - From ABC to PhD, Copenhagen Business School, Denmark, 2014.

[20] Rosendahl Huber, L., Sloof, R., \& Praag, M. The effect of Early Entrepreneurship Education: Evidence from a Randomized field experiment, Tinbergen Institute Discussion Paper, No. 6512, 2012.
[21] Deuchar, R. 'Not only this, but also that!' Translating the social and political motivations underpinning enterprise and citizenship education into Scottish schools, Taylor \& Francis, Cambridge Journal of Education, Vol. 36, No. 4, 533-547, 2006.

[22] Leffler, E. \& Näsström, G. Entrepreneurial learning and school improvement a Swedish case, ARC, International Journal of Humanities, Social Science and Education (IJHSSE), Vol. 1, No.11, 2014.

[23] Surlemont, B. Promoting enterprising: A strategic move to get schools' cooperation in the promotion of entrepreneurship. In A. Fayolle (ED.), Handbook of research in entrepreneurship education, Volume 2 - Contextual perspectives, Edward Elgar, Great Britain, 2007.

[24] Falk-Lundqvist, Å., Hallberg, P-G., Leffler, E. \& Svedberg, G. Entrepreneöriellt lärande - i teori och praktik, Liber, Sweden, 2011

[25] Røe Ødegård, I K. Pedagogiskt entreprenørskap i lærerutdanningen: en framtidsrettet læringsstrategi, Cappelen Damm Akademisk, Norway, 2014

[26] Rae, D. Understanding entrepreneurial learning: A question of how?, Emerald, International Journal of Educational Behaviour \& Research, Vol. 6, no. 3, 145-159, 2000.

[27] Pepin, M. Enterprise education: A Deweyan perspective, Emerald, Education + Traning, Vol. 54, No. 8/9, 801-812, 2012.

[28] Backström-Widjeskog, B. Du kan om du vill - lärares tankar om fostran till företagsamhet. Åbo Akademis Förlag, Finland, 2008.

[29] Berglund, K. \& Holmgren, C. Entreprenörskap i skolan: Vad berättar lärare att de "gör" när de gör entreprenörskap i skolan?, Forum för småföretagsforskning, Sweden, 2007.

[30] Bager, T. \& Løwe Nielsen, S. Entreprenørskap og kompetenser: GEM-antologi, Børsen, Denmark, 2009.

[31] Leffler, E. Enterprise learning and school subjects - A subject didactic issue, Macrothink Institute, Journal of Education and Training, Vol. 1, No 1, 15-30, 2014

[32] Government office of Sweden, Strategi för entreprenörskap inom utbildningsområdet, Regeringskansliet, Sweden, 2009.

[33] Cohen, L., Manion, L. \&Morison, K. Research Methods in Education, Routledge, Great Britain, 2011.

[34] Kvale, S. Den kvalitativa forskningsintervjun, Studentlitteratur, Sweden, 1997.

[35] Kullberg, B. Etnografi i klassrummet, Studentlitteratur, Sweden, 1996.

[36] Scherp, H-Å. Lärandebaserad skolutveckling - lärglädjens förutsättningar, förverkligande och resultat, Studentlitteratur, Sweden, 2014.

[37] Fink and Stoll, Educational Change: Easier Said than Done. In A. Hargreaves (ed.), Extending Educational Change, Springer, Netherlands, 2005 
[38] Rönnberg, L. Reinstating national school inspections in Sweden, In M. Lawn \& R. Normand, Shaping of European Education, Interdisciplinary approaches, Routledge, Great Britain, 2012

[39] (Biesta, G. Good education in an age of measurement: on the need to reconnect with the question of purpose in education,
Springer, Educational Assessment, Evaluation and Accountability, Vol. 21, No. 33, 33-46, 2009

[40] Olovsson, T.G. Det kontrollera(n)de klassrummet. Bedömningsprocessen i svensk grundskolpraktik i relation till införandet av nationella skolreformer. Umeå: Umeå universitet, Pedagogiska institutionen, 2015. 